Vol 1. No 1. Juli 2021 e-ISSN : 2798-5733 P-ISSN : 2798-5741

\title{
PENERAPAN METODE DEMONSTRASI (برهنة) UNTUK MENINGKATKAN PRESTASI BELAJAR BAHASA ARAB PADA SISWA KELAS 8B MTsN 8 NGAWI
}

\author{
MUKHOYYAROH \\ Mtsn 8 Ngawi \\ e-mail: mukhoyyarohy@gmail.com
}

\begin{abstract}
ABSTRAK
Berhasilnya tujuan pembelajaran ditentukan oleh banyak faktor, diantaranya adalah faktor guru dalam melaksanakan proses belajar mengajar, karena dengan memilih dan menggunakan metode yang tepat dan sesuai dengan materi pelajaran atau pokok bahasannya, maka siswa dengan mudah dapat menerima pelajaran yang disampaiakan. Permasalahan yang ingin dikaji dalam penelitian ini adalah: (a) Bagaimanakah peningkatan prestasi belajar bahasa Arab dengan diterapkannya metode demonstrasi (برهنة)? (b) Bagaimanakah pengaruh metode demonstrasi terhadap motivasi belajar siswa? Tujuan dari penelitian ini adalah: (a) Ingin mengetahui peningkatan prestasi belajar siswa setelah diterapkannya metode demonstrasi (برهنة) (b) Ingin mengetahui pengaruh metode demonstrasi (برهنة) terhadap motivasi belajar siswa. Penelitian ini menggunakan penelitian tindakan (action research) sebanyak tiga putaran. Setiap putaran terdiri dari empat tahap yaitu: rancangan, kegiatan dan pengamatan, refleksi, dan revisi. Sasaran penelitian ini adalah siswa kelas 8B MTsN 8 Ngawi. Data yang diperoleh berupa hasil tes formatif. Dari hasil analisis didapatkan bahwa prestasi belajar siswa mengalami peningkatan dari siklus I sampai siklus III yaitu, siklus I (70,00\%), siklus II (76,67\%), siklus III $(86,67 \%)$. Simpulan dari penelitian ini adalah metode demonstrasi (برهنة) dapat berpengaruh positif terhadap prestasi belajar dan dapat meningkatkan motivasi belajar siswa kelas 8B MTsN 8 Ngawi, serta penggunaan metode demonstrasi (برهنة) ini dapat digunakan sebagai salah satu alternatif dalam pembelajaran bahasa Arab.
\end{abstract}

Kata Kunci: Metode Demonstrasi (برهنة), Prestasi Belajar

\section{PENDAHULUAN}

Pada hakekatnya kegiatan belajar mengajar adalah suatu proses interaksi atau hubungan timbal balik antara guru dan siswa dalam satuan pembelajaran. Guru sebagai salah satu komponen dalam proses belajar menganjar merupakan pemegang peran yang sangat penting. Guru bukan hanya sekedar penyampai materi saja, tetapi lebih dari itu guru dapat dikatakan sebagai sentral pembelajaran. Sebagai pengatur sekaligus pelaku dalam proses belajar mengajar, gurulah yang mengarahkan bagaimana proses belajar mengajar itu dilaksanakan. Karena itu guru harus dapat membuat suatu pengajaran menjadi lebih efektif dan menarik sehingga bahan pelajaran yang disampaikan akan membuat siswa merasa senang dan merasa perlu untuk mempelajari bahan pelajaran tersebut.

Guru mengemban tugas yang berat untuk tercapainya tujuan pendidikan nasional yaitu meningkatkan kualitas manusia Indonesia seutuhnya yang beriman dan bertakwa terhadap Tuhan Yang Maha Esa, berbudi pekerti luhur, berkepribadian, berdisiplin, bekerja keras, tangguh, bertanggung jawab, mandiri, cerdas dan terampil serta sehat jasmani dan rohani, juga harus mampu menumbuhkan dan memperdalam rasa cinta terhadap tanah air, mempertebal semangat kebangsaan dan rasa kesetiakawanan sosial. Sejalan dengan itu pendidikan nasional akan mampu mewujudkan manusia-manusia pembangunan dan membangun dirinya sendiri serta bertanggung jawab atas pembangunan bangsa.

Berhasilnya tujuan pembelajaran ditentukan oleh banyak faktor diantaranya adalah faktor guru dalam melaksanakan proses belajar mengajar, karena guru secara langsung dapat mempengaruhi, membina dan meningkatkan kecerdasan serta keterampilan siswa. Untuk mengatasi permasalahan di atas dan guna mencapai tujuan pendidikan secara maksimal, peran guru sangat penting dan diharapkan guru memiliki cara/model mengajar yang baik dan mampu 
memilih model pembelajaran yang tepat dan sesuai dengan konsep-konsep mata pelajaran yang akan disampaikan.

Tujuan pendidikan nasional seperti yang terdapat dalam Undang-undang Nomor 20 tahuan 2003 yaitu mencerdaskan kehidupan bangsa dan mengembangkan manusia Indonesia yang beriman dan bertakwa terhadap Tuhan Yang Maha Esa dan berbudi luhur, memiliki pengetahuan dan keterampilan, sehat jasmani dan rohani kepribadian yang mantap dan mandiri serta bertanggung jawab kemasyarakatan bangsa. Dalam mencapai tujuan pembelajaran pada mata pelajaran Bahasa Arab di Madrasah Tsanawiyah Negeri 8 Ngawi khususnya di kelas 8B tahun pelajaran 2017/2018 masih banyak mengalami kesulitan. Hal ini terlihat dari masih rendahnya nilai mata pelajaran bahasa Arab dibandingkan dengan nilai beberapa mata pelajaran lainnya. Bertitik tolak dari hal tersebut di atas perlu pemikiran-pemikiran dan tindakan-tindakan yang harus dilalukan agar siswa dalam mempelajari bahasa Arab tidak mengalami kesulitan, sehingga tujuan pembelajaran yang dibuat oleh guru mata pelajaran bahasa Arab dapat tercapai dengan baik dan hasilnya dapat memuaskan semua pihak. Oleh sebab itu penggunaan metode pembelajaran dirasa sangat penting untuk membantu siswa dalam mempelajari bahasa Arab.

Metode pembelajaran jenisnya beragam dan masing-masing memiliki kelebihan dan kelemahan, maka pemilihan metode yang sesuai dengan topik atau pokok bahasan yang akan diajarkan harus betul-betul dipikirkan oleh guru yang akan menyampaikan materi pelajaran.

Sedangkan penggunaan metode demonstrasi (برهنة) diharapkan dapat meningkatkan aktivitas siswa dalam proses belajar mengajar sehingga dalam proses belajar mengajar itu aktifitasnya tidak hanya didominasi oleh guru. Dengan demikian siswa akan terlibat secara fisik, emosional dan intelektual yang pada gilirannya diharapkan konsep perubahan benda yang diajarkan oleh guru dapat dipahami oleh siswa. Berdasarkan uraian dari latar belakang tersebut di atas maka dalam penelitian ini memilih judul "Penerapan Metode Demonstrasi (بر هنة) Untuk Meningkatkan Prestasi Belajar Bahasa Arab Pada Siswa Kelas 8B Madrasah Tsanawiyah Negeri 8 Ngawi Tahun Pelajaran 2017/2018."

\section{METODE PENELITIAN}

Penelitian ini merupakan penelitian tindakan (action research), karena penelitian dilakukan untuk memecahkan masalah pembelajaran di kelas. Penelitian ini juga termasuk penelitian deskriptif, sebab menggambarkan bagaimana suatu teknik pembelajaran diterapkan dan bagaimana hasil yang diinginkan dapat dicapai. Tempat penelitian adalah tempat yang digunakan dalam melakukan penelitian untuk memperoleh data yang diinginkan. Penelitian ini bertempat di Kelas 8B Madrasah Tsanawiyah Negeri 8 Ngawi Tahun Pelajaran 2017/2018. Waktu penelitian adalah waktu berlangsungnya penelitian atau saat penelitian ini dilangsungkan. Penelitian ini dilaksanakan pada bulan Februari semester genap tahun pelajaran 2017/2018. Subyek penelitian di sini adalah siswa kelas 8B Madrasah Tsanawiyah Negeri 8 Ngawi tahun pelajaran 2017/2018 pada pokok bahasan الهواية

\section{HASIL DAN PEMBAHASAN}

\section{A. Hasil}

Data penelitian yang diperoleh berupa hasil uji coba item butir soal, data observasi berupa pengamatan pengelolaan belajar dengan metode demonstrasi (برهنة) dan pengamatan aktivitas siswa dan guru pada akhir pembelajaran dan data tes formatif siswa pada setiap siklus. Data hasil uji coba item butir soal digunakan untuk mendapatkan tes yang betul-betul mewakili apa yang diinginkan. Data ini selanjutnya dianalisis tingkat validitas, reliabilitas, taraf kesukaran, dan daya pembeda. Data tes formatif untuk mengetahui peningkatan prestasi belajar siswa setelah diterapkan belajar dengan metode demonstrasi (برهنة). 


\section{Siklus I}

1) Tahap Perencanaan

Pada tahap ini peneliti mempersiapkan perangkat pembelajaran yang terdiri dari rencana pelajaran 1 , LKS 1 , soal tes formatif 1 dan alat-alat pengajaran yang mendukung.

2) Tahap Kegiatan dan Pelaksanaan

Pelaksanaan kegiatan belajar mengajar untuk siklus I dilaksanakan pada tanggal 6 Februari 2018 di kelas 8B dengan jumlah siswa 30 anak. Dalam hal ini peneliti bertindak sebagai guru. Adapun proses belajar mengajar mengacu pada rencana pelajaran yang telah dipersiapkan. Pengamatan (observasi) dilaksanakan bersamaan dengan pelaksaaan belajar mengajar. Pada akhir proses belajar mengajar siswa diberi tes formatif I dengan tujuan untuk mengetahui tingkat keberhasilan siswa dalam proses belajar mengajar yang telah dilakukan. Adapun data hasil penelitian pada siklus I adalah sebagai berikut:

Table 1. Distribusi Nilai Tes Pada Siklus I

\begin{tabular}{|c|c|c|c|c|}
\hline \multirow{2}{*}{$\begin{array}{l}\text { No. } \\
\text { Urut }\end{array}$} & \multirow{2}{*}{ Nama Siswa } & \multirow{2}{*}{$\begin{array}{l}\text { Nilai Yang } \\
\text { Diperoleh }\end{array}$} & \multicolumn{2}{|c|}{ Keterangan } \\
\hline & & & $\mathbf{T}$ & TT \\
\hline 1 & Aisma Fitri Handayani & 90 & $\sqrt{ }$ & \\
\hline 2 & Aisyah Putri Oktaviani & 95 & $\sqrt{ }$ & \\
\hline 3 & Anissa Yuniarsih & 90 & $\sqrt{ }$ & \\
\hline 4 & Annisa Nurhayati & 75 & $\sqrt{ }$ & \\
\hline 5 & Aulia Anindya J. & 90 & $\sqrt{ }$ & \\
\hline 6 & Ayu Rohmana & 85 & $\sqrt{ }$ & \\
\hline 7 & Beta Meity Nurisa & 75 & $\sqrt{ }$ & \\
\hline 8 & Dini Rahmawati & 95 & $\sqrt{ }$ & \\
\hline 9 & Gita Apriliana & 96 & $\sqrt{ }$ & \\
\hline 10 & Khusnul Dwi Wahyuni & 80 & $\sqrt{ }$ & \\
\hline 11 & Mayang Fatikha $S$. & 96 & $\sqrt{ }$ & \\
\hline 12 & Novita Purwanti & 95 & $\sqrt{ }$ & \\
\hline 13 & Rini Agustin & 95 & $\sqrt{ }$ & \\
\hline 14 & Yunita Mukti Triningsih & 96 & $\sqrt{ }$ & \\
\hline 15 & Akhmad Akmal F. & 95 & $\sqrt{ }$ & \\
\hline 16 & Cheryy Tegar P. & 70 & & $\sqrt{ }$ \\
\hline 17 & Fahrul Syarifudin & 65 & & $\sqrt{ }$ \\
\hline 18 & Faizal & 80 & $\sqrt{ }$ & \\
\hline 19 & Faizal Maulana A. & 45 & & $\sqrt{ }$ \\
\hline
\end{tabular}




\begin{tabular}{|l|l|l|l|l|}
\hline 20 & Hendri Suryadi & 80 & $\sqrt{ }$ & \\
\hline 21 & Heru Hermawan & 85 & $\sqrt{ }$ & \\
\hline 22 & Mashud Arriza P. & 65 & & $\sqrt{ }$ \\
\hline 23 & Muh. Farhan Akbar & 95 & $\sqrt{ }$ & \\
\hline 24 & Nur Alim & 80 & $\sqrt{ }$ & \\
\hline 25 & Taufik Hidayat & 65 & & $\sqrt{ }$ \\
\hline 26 & Umar Muwalit & 85 & $\sqrt{ }$ & \\
\hline 27 & Viyonico Gunari & 65 & & $\sqrt{ }$ \\
\hline 28 & Wisnu Aji Saputra & 55 & & $\sqrt{ }$ \\
\hline 29 & Yusuf Yulianto & 65 & & $\sqrt{ }$ \\
\hline 30 & Yuwono Wahyu S. & 40 & & $\sqrt{ }$ \\
\hline & Jumlah & 2388 & 21 & 9 \\
\hline & Jumlah Skor & 2388 & & \\
\hline & Jumlah Skor Maksimal & 3000 & & \\
\hline & Rata-rata Skor Tercapai & 79,60 & & \\
\hline
\end{tabular}

$\begin{array}{lll}\text { Keterangan: } & \text { T } \quad \text { : Tuntas } & \\ & \text { TT : Tidak Tuntas } & : 21 \\ & \text { Jumlah siswa yang tuntas } & : 9 \\ & \text { Jumlah siswa yang belum tuntas } & : \text { Belum tuntas } \\ & \text { Klasikal }\end{array}$

Tabel 2. Rekapitulasi Hasil Tes Pada Siklus I

\begin{tabular}{|l|l|l|}
\hline No & \multicolumn{1}{|c|}{ Uraian } & Hasil Siklus I \\
\hline 1 & Nilai rata-rata formatif & 79,60 \\
\hline 2 & Jumlah siswa yang tuntas belajar & 21 \\
\hline 3 & Persentase ketuntasan belajar & 70,00 \\
\hline
\end{tabular}

Dari tabel di atas dapat dijelaskan bahwa dengan menerapkan metode demonstrasi (برهنة) diperoleh nilai rata-rata prestasi belajar siswa adalah 79,60 dan ketuntasan belajar mencapai $70,00 \%$ atau ada 21 siswa dari 30 siswa sudah tuntas belajar. Hasil tersebut menunjukkan bahwa pada siklus pertama secara klasikal siswa belum tuntas belajar, karena siswa yang memperoleh nilai $\geq 75$ hanya sebesar $70,00 \%$ lebih kecil dari persentase ketuntasan yang dikehendaki yaitu sebesar $85 \%$. Hal ini disebabkan karena siswa masih merasa baru dan belum mengerti apa yang dimaksudkan dan digunakan guru dengan menerapkan metode demonstrasi (بر هنة). 


\section{Siklus II}

1) Tahap perencanaan

Pada tahap ini peneliti mempersiapkan perangkat pembelajaran yang terdiri dari rencana pelajaran 2, LKS 2, soal tes formatif II dan alat-alat pengajaran yang mendukung.

2) Tahap kegiatan dan pelaksanaan

Pelaksanaan kegiatan belajar mengajar untuk siklus II dilaksanakan pada tanggal 13 Februari 2018 di kelas 8B dengan jumlah siswa 30 anak. Dalam hal ini peneliti bertindak sebagai guru. Adapun proses belajar mengajar mengacu pada rencana pelajaran dengan memperhatikan revisi pada siklus I, sehingga kesalahan atau kekurangan pada siklus I tidak terulang lagi pada siklus II. Pengamatan (observasi) dilaksanakan bersamaan dengan pelaksanaan belajar mengajar. Pada akhir proses belajar mengajar siswa diberi tes formatif II dengan tujuan untuk mengetahui tingkat keberhasilan siswa dalam proses belajar mengajar yang telah dilakukan. Instrumen yang digunakan adalah tes formatif II. Adapun data hasil penelitian pada siklus II adalah sebagai berikut.

Table 3. Distribusi Nilai Tes Pada Siklus II

\begin{tabular}{|c|c|c|c|c|}
\hline \multirow{2}{*}{$\begin{array}{l}\text { No. } \\
\text { Urut }\end{array}$} & \multirow{2}{*}{ Nama Siswa } & \multirow{2}{*}{$\begin{array}{l}\text { Nilai Yang } \\
\text { Diperoleh }\end{array}$} & \multicolumn{2}{|c|}{ Keterangan } \\
\hline & & & $\mathbf{T}$ & TT \\
\hline 1 & Aisma Fitri Handayani & 92 & $\sqrt{ }$ & \\
\hline 2 & Aisyah Putri Oktaviani & 95 & $\sqrt{ }$ & \\
\hline 3 & Anissa Yuniarsih & 92 & $\sqrt{ }$ & \\
\hline 4 & Annisa Nurhayati & 77 & $\sqrt{ }$ & \\
\hline 5 & Aulia Anindya J. & 90 & $\sqrt{ }$ & \\
\hline 6 & Ayu Rohmana & 87 & $\sqrt{ }$ & \\
\hline 7 & Beta Meity Nurisa & 77 & $\sqrt{ }$ & \\
\hline 8 & Dini Rahmawati & 95 & $\sqrt{ }$ & \\
\hline 9 & Gita Apriliana & 96 & $\sqrt{ }$ & \\
\hline 10 & Khusnul Dwi Wahyuni & 82 & $\sqrt{ }$ & \\
\hline 11 & Mayang Fatikha S. & 96 & $\sqrt{ }$ & \\
\hline 12 & Novita Purwanti & 95 & $\sqrt{ }$ & \\
\hline 13 & Rini Agustin & 95 & $\sqrt{ }$ & \\
\hline 14 & Yunita Mukti Triningsih & 96 & $\sqrt{ }$ & \\
\hline 15 & Akhmad Akmal F. & 95 & $\sqrt{ }$ & \\
\hline 16 & Cheryy Tegar P. & 75 & $\sqrt{ }$ & \\
\hline 17 & Fahrul Syarifudin & 75 & $\sqrt{ }$ & \\
\hline
\end{tabular}




\begin{tabular}{|l|l|l|l|l|}
\hline 18 & Faizal & 82 & $\sqrt{ }$ & \\
\hline 19 & Faizal Maulana A. & 60 & & $\sqrt{ }$ \\
\hline 20 & Hendri Suryadi & 80 & $\sqrt{ }$ & \\
\hline 21 & Heru Hermawan & 85 & $\sqrt{ }$ & \\
\hline 22 & Mashud Arriza P. & 70 & & $\sqrt{ }$ \\
\hline 23 & Muh. Farhan Akbar & 95 & $\sqrt{ }$ & \\
\hline 24 & Nur Alim & 82 & $\sqrt{ }$ & \\
\hline 25 & Taufik Hidayat & 70 & & $\sqrt{ }$ \\
\hline 26 & Umar Muwalit & 85 & $\sqrt{ }$ & \\
\hline 27 & Viyonico Gunari & 70 & & $\sqrt{ }$ \\
\hline 28 & Wisnu Aji Saputra & 60 & & $\sqrt{ }$ \\
\hline 29 & Yusuf Yulianto & 65 & & $\sqrt{ }$ \\
\hline 30 & Yuwono Wahyu S. & 50 & 23 & 7 \\
\hline & Jumlah & 2464 & & \\
\hline & Jumlah Skor & 2464 & & \\
\hline & Jumlah Skor Maksimal & 3000 & & \\
\hline & Rata-rata Skor Tercapai & 82,13 & & \\
\hline
\end{tabular}

\begin{tabular}{lll}
\hline Keterangan: & T & $:$ Tuntas \\
& TT & $:$ Tidak Tuntas
\end{tabular}

Jumlah siswa yang tuntas $\quad: 23$

Jumlah siswa yang belum tuntas $: 7$

Klasikal : Belum tuntas

Tabel 4. Rekapitulasi Hasil Tes Pada Siklus II

\begin{tabular}{|l|l|l|}
\hline No & Uraian & Hasil Siklus I \\
\hline 1 & Nilai rata-rata formatif & 82,13 \\
\hline 2 & Jumlah siswa yang tuntas belajar & 23 \\
\hline 3 & Persentase ketuntasan belajar & 76,67 \\
\hline
\end{tabular}

Dari tabel di atas diperoleh nilai rata-rata prestasi belajar siswa adalah 82,13 dan ketuntasan belajar mencapai $76,67 \%$ atau ada 23 siswa dari 30 anak sudah tuntas belajar. Hasil ini menunjukkan bahwa pada siklus II ini ketuntasan belajar secara klasikal telah mengalami peningkatan sedikit lebih baik dari siklus I. Adanya peningkatan hasil belajar siswa ini karena setelah guru menginformasikan bahwa setiap 
akhir pelajaran akan selalu diadakan tes sehingga pada pertemuan berikutnya siswa lebih termotivasi untuk belajar. Selain itu siswa juga sudah mulai mengerti apa yang dimaksudkan dan dinginkan guru dengan menerapkan metode demonstrasi (بر هنة).

\section{Siklus III}

1) Tahap Perencanaan

Pada tahap ini peneliti mempersiapkan perangkat pembelajaran yang terdiri dari rencana pelajaran 3 , LKS 3, soal tes formatif 3 dan alat-alat pengajaran yang mendukung.

2) Tahap kegiatan dan pengamatan

Pelaksanaan kegiatan belajar mengajar untuk siklus III dilaksanakan pada tanggal 20 Februari 2018 di kelas 8B dengan jumlah siswa 30 anak. Dalam hal ini peneliti bertindak sebagai guru. Adapun proses belajar mengajar mengacu pada rencana pelajaran dengan memperhatikan revisi pada siklus II, sehingga kesalahan atau kekurangan pada siklus II tidak terulang lagi pada siklus III. Pengamatan (observasi) dilaksanakan bersamaan dengan pelaksanaan belajar mengajar. Pada akhir proses belajar mengajar siswa diberi tes formatif III dengan tujuan untuk mengetahui tingkat keberhasilan siswa dalam proses belajar mengajar yang telah dilakukan. Instrumen yang digunakan adalah tes formatif III. Adapun data hasil penelitian pada siklus III adalah sebagai berikut :

Tabel 5. Distribusi Nilai Tes Pada Siklus III

\begin{tabular}{|l|l|l|l|l|}
\hline \multirow{2}{*}{$\begin{array}{l}\text { No. } \\
\text { Urut }\end{array}$} & \multirow{2}{*}{ Nama Siswa } & \multirow{2}{*}{$\begin{array}{l}\text { Nilai Yang } \\
\text { Diperoleh }\end{array}$} & \multicolumn{2}{|l|}{ Keterangan } \\
\cline { 5 - 6 } & & & T & TT \\
\hline 1 & Aisma Fitri Handayani & 94 & $\sqrt{ }$ & \\
\hline 2 & Aisyah Putri Oktaviani & 95 & $\sqrt{ }$ & \\
\hline 3 & Anissa Yuniarsih & 94 & $\sqrt{ }$ & \\
\hline 4 & Annisa Nurhayati & 80 & $\sqrt{ }$ & \\
\hline 5 & Aulia Anindya J. & 92 & $\sqrt{ }$ & \\
\hline 6 & Ayu Rohmana & 88 & $\sqrt{ }$ & \\
\hline 7 & Beta Meity Nurisa & 80 & $\sqrt{ }$ & \\
\hline 8 & Dini Rahmawati & 97 & $\sqrt{ }$ & \\
\hline 9 & Gita Apriliana & 100 & $\sqrt{ }$ & \\
\hline 10 & Khusnul Dwi Wahyuni & 85 & $\sqrt{ }$ & \\
\hline 11 & Mayang Fatikha Syafitri & 100 & $\sqrt{ }$ & \\
\hline 12 & Novita Purwanti & 97 & $\sqrt{ }$ & \\
\hline 13 & Rini Agustin & 97 & $\sqrt{ }$ & \\
\hline 14 & Yunita Mukti Triningsih & 100 & $\sqrt{ }$ & \\
\hline 15 & Akhmad Akmal Fauzan & 96 & & \\
\hline
\end{tabular}




\begin{tabular}{|c|c|c|c|c|}
\hline 16 & Cheryy Tegar Pambodo & 77 & $\sqrt{ }$ & \\
\hline 17 & Fahrul Syarifudin & 77 & $\sqrt{ }$ & \\
\hline 18 & Faizal & 85 & $\sqrt{ }$ & \\
\hline 19 & Faizal Maulana Azrorur & 65 & & $\sqrt{ }$ \\
\hline 20 & Hendri Suryadi & 82 & $\sqrt{ }$ & \\
\hline 21 & Heru Hermawan & 87 & $\sqrt{ }$ & \\
\hline 22 & Mashud Arriza P. & 75 & $\sqrt{ }$ & \\
\hline 23 & Muh. Farhan Akbar & 96 & $\sqrt{ }$ & \\
\hline 24 & Nur Alim & 84 & $\sqrt{ }$ & \\
\hline 25 & Taufik Hidayat & 75 & $\sqrt{ }$ & \\
\hline 26 & Umar Muwalit & 87 & $\sqrt{ }$ & \\
\hline 27 & Viyonico Gunari & 75 & $\sqrt{ }$ & \\
\hline 28 & Wisnu Aji Saputra & 65 & & $\sqrt{ }$ \\
\hline 29 & Yusuf Yulianto & 67 & & $\sqrt{ }$ \\
\hline \multirow[t]{5}{*}{30} & Yuwono Wahyu Saputro & 60 & & $\sqrt{ }$ \\
\hline & Jumlah & 2552 & 26 & 4 \\
\hline & Jumlah Skor & 2552 & & \\
\hline & Jumlah Skor Maksimal & 3000 & & \\
\hline & Rata-rata Skor Tercapai & 84,76 & & \\
\hline
\end{tabular}

$\begin{array}{lll}\text { Keterangan: } & \text { T } & \\ & \text { TT Tuntas } & \text { : Tidak Tuntas } \\ \text { Jumlah siswa yang tuntas } & : 26 \\ & \text { Jumlah siswa yang belum tuntas } & : 4 \\ \text { Klasikal } & : \text { Belum tuntas }\end{array}$

Tabel 6 Rekapitulasi Hasil Tes Pada Siklus III

\begin{tabular}{|l|l|l|}
\hline No & Uraian & Hasil Siklus III \\
\hline 1 & Nilai rata-rata formatif & 84,76 \\
\hline 2 & Jumlah siswa yang tuntas belajar & 26 \\
\hline 3 & Persentase ketuntasan belajar & 86,67 \\
\hline
\end{tabular}

Berdasarkan tabel diatas diperoleh nilai rata-rata tes formatif sebesar 84,76 dan dari 30 siswa yang telah tuntas sebanyak 26 siswa dan 4 siswa belum mencapai ketuntasan belajar. Maka secara klasikal ketuntasan belajar yang telah tercapai sebesar 
86,67 \% (termasuk kategori tuntas). Hasil pada siklus III ini mengalami peningkatan lebih baik dari siklus II. Adanya peningkatan hasil belajar pada siklus III ini dipengaeruhi oleh adanya peningkatan kemampuan guru dalam menerapkan belajar dengan metode demonstrasi (برهنة) sehingga siswa menjadi lebih terbiasa dengan pembelajaran seperti ini sehingga siswa lebih mudah dalam memahami materi yang telah diberikan.

\section{Refleksi}

Pada tahap ini akah dikaji apa yang telah terlaksana dengan baik maupun yang masih kurang baik dalam proses belajar mengajar dengan penerapan metode demonstrasi (برهنة). Dari data-data yang telah diperoleh dapat diuraikan sebagai berikut:

1) Selama proses belajar mengajar guru telah melaksanakan semua pembelajaran dengan baik. Meskipun ada beberapa aspek yang belum sempurna, tetapi persentase pelaksanaannya untuk masing-masing aspek cukup besar.

2) Berdasarkan data hasil pengamatan diketahui bahwa siswa aktif selama proses belajar berlangsung.

3) Kekurangan pada siklus-siklus sebelumnya sudah mengalami perbaikan dan peningkatan sehingga menjadi lebih baik.

4) Hasil belajar siswsa pada siklus III mencapai ketuntasan.

\section{Revisi Pelaksanaan}

Pada siklus III guru telah menerapkan belajar dengan metode demonstrasi (بر هنة) dengan baik dan dilihat dari aktivitas siswa serta hasil belajar siswa pelaksanaan proses belajar mengajar sudah berjalan dengan baik. Maka tidak diperlukan revisi terlalu banyak, tetapi yang perlu diperhatikan untuk tindakah selanjutnya adalah memaksimalkan dan mempertahankan apa yang telah ada dengan tujuan agar pada pelaksanaan proses belajar mengajar selanjutnya penerapan metode demonstrasi (بر هنة) dapat meningkatkan proses belajar mengajar sehingga tujuan pembelajaran dapat tercapai.

\section{B. Pembahasan}

1. Ketuntasan Hasil belajar Siswa

Melalui hasil peneilitian ini menunjukkan bahwa metode demonstrasi (بر هنة) memiliki dampak positif dalam meningkatkan prestasi belajar siswa. Hal ini dapat dilihat dari semakin mantapnya pemahaman siswa terhadap materi yang disampaikan guru (ketuntasan belajar meningkat dari sklus I, II, dan III) yaitu masing-masing 70,00 $\%, 76,67 \%$, dan 86,67 \%. Pada siklus III ketuntasan belajar siswa secara klasikal telah tercapai.

2. Kemampuan Guru dalam Mengelola Pembelajaran

Berdasarkan analisis data, diperoleh aktivitas siswa dalam proses pembelajaran dalam setiap siklus mengalami peningkatan. Hal ini berdampak positif terhadap prestasi belajar siswa yaitu dapat ditunjukkan dengan meningkatnya nilai rata-rata siswa pada setiap siklus yang terus mengalami peningkatan.

3. Aktivitas Guru dan Siswa Dalam Pembelajaran

Berdasarkan analisis data, diperoleh aktifitas siswa dalam proses pembelajaran bahasa Arab pada pokok bahasan الهو اية dengan metode demonstrasi (برهنة) yang paling dominan adalah mendengarkan/ memperhatikan penjelasan guru, dan diskusi antar siswa/antara siswa dengan guru. Jadi dapat dikatakan bahwa aktifitas siswa dapat dikategorikan aktif.

Sedangkan untuk aktifitas guru selama pembelajaran telah melaksanakan langkah-langkah belajar dengan metode demonstrasi (برهنة) dengan baik. Hal ini terlihat dari aktifitas guru yang muncul di antaranya aktifitas membimbing dan mengamati siswa dalam mengerjakan kegiatan LKS/menemukan konsep, menjelaskan, memberi 
umpan balik/evaluasi/tanya jawab dimana prosentase untuk aktifitas di atas cukup besar.

\section{KESIMPULAN}

Dari hasil kegiatan pembelajaran yang telah dilakukan selama tiga siklus, dan berdasarkan seluruh pembahasan serta analisis yang telah dilakukan dapat disimpulkan sebagai berikut:

1. Pembelajaran dengan metode demonstrasi (برهنة) memiliki dampak positif dalam meningkatkan prestasi belajar siswa yang ditandai dengan peningkatan ketuntasan belajar siswa dalam setiap siklus, yaitu siklus I ( 70,00 \% ), siklus II ( 76,67 \% ), siklus III ( $86,67 \%)$.

2. Penerapan metode demonstrasi (برهنة) mempunyai pengaruh positif, yaitu dapat meningkatkan motivasi belajar siswa yang ditunjukan dengan rata-rata jawaban siswa hasil wawancara yang menyatakan bahwa siswa tertarik dan berminat dengn metode demonstrasi (بر هنة) sehingga mereka menjadi termotivasi untuk belajar.

\section{DAFTAR PUSTAKA}

Ali, Muhammad. (1996). Guru Dalam Proses Belajar Mengajar. Bandung: Sinar Baru Algesindon.

Arikunto, Suharsimi. (1993). Manajemen Mengajar Secara Manusiawi. Jakarta: Rineksa Cipta. Arikunto, Suharsimi. (1998). Prosedur Penelitian Suatu Pendekatan Praktek. Jakarta: Rineksa Cipta

Combs. Arthur. W. (1984). The Profesional Education of Teachers. Allin and Bacon, Inc. Boston.

Dahar, R.W. (1989). Teori-teori Belajar. Jakarta: Erlangga.

Departemen Pendidikan dan Kebudayaan. (1994). Petunjuk Pelaksanaan Proses Belajar Mengajar. Jakarta. Balai Pustaka.

Djamarah, Syaiful Bahri. (2000). Strategi Belajar Mengajar. Jakarta: Rineksa Cipta.

Hadi, Sutrisno. (1981). Metodogi Research. Yoyakarta : Yayasan Penerbitan Fakultas Psikologi Universitas Gajah Mada..

Hadi, Sutrisno. (1982). Metodologi Research, Jilid 1. Yogyakarta: YP. Fak. Psikologi UGM. Hamalik, Oemar. (1994). Metode Pendidikan. Bandung: Citra Aditya Bakti.

Hasibuan. J.J. dan Moerdjiono. (1998). Proses Belajar Mengajar. Bandung: Remaja Rosdakarya.

Hudoyo, H. (1990). Strategi Belajar Mengajar Matematika. Malang: IKIP Malang.

Kemmis, S. dan Mc. Taggart, R. (1988). The Action Research Planner. Victoria Dearcin University Press.

Margono. (1997). Metodologi Penelitian Pendidikan. Jakarta. Rineksa Cipta.

Mursell, James ( t.t ). Succesfull Teaching (terjemahan). Bandung: Jemmars.

Ngalim, Purwanto M. (1990). Psikologi Pendidikan. Bandung: PT. Remaja Rosdakarya.

Purwanto, N. (1988). Prinsip-prinsip dan Teknis Evaluasi Pengajaran. Bandung. Remaja Rosda Karya.

Rustiyah, N.K. (1991). Strategi Belajar Mengajar. Jakarta: Bina Aksara.

Saliwangi, B. (1988). Pengantar Strategi Belajar Mengajar Bahasa Indonesia. Malang: IKIP Malang.

Sardiman, A.M. (1996). Interaksi dan Motivasi Belajar Mengajar. Jakarta: Bina Aksara.

Soekamto, Toeti. (1997). Teori Belajar dan Model Pembelajaran. Jakarta: PAU-PPAI, Universitas Terbuka.

Syah, Muhibbin. (1995). Psikologi Pendidikan, Suatu Pendekatan Baru. Bandung: Remaja Rosdakarya.

Usman, Moh. Uzer. (2001). Menjadi Guru Profesional. Bandung: Remaja Rosdakarya.

Wetherington. H.C. and W.H. Walt. Burton. (1986). Teknik-teknik Belajar dan Mengajar. (terjemahan). Bandung: Jemmars. 